\title{
Evidence against PALB2 involvement in Icelandic breast cancer susceptibility
} Haukur Gunnarsson1, Adalgeir Arason1, Elizabeth M Gillanders², Bjarni A Agnarsson ${ }^{1}$, Gudrun Johannesdottir ${ }^{1}$, Oskar Th Johannsson ${ }^{3}$ and Rosa B Barkardottir*1

Address: ${ }^{1}$ Department of Pathology, Landspitali - University Hospital, Reykjavik, Iceland, ${ }^{2}$ Inherited Disease Research Branch, National Human Genome Research Institute, NIH, Baltimore, Maryland, USA and ${ }^{3}$ Department of Oncology, Landspitali - University Hospital, Reykjavik, Iceland Email: Haukur Gunnarsson - haukur@landspitali.is; Adalgeir Arason - adalgeir@landspitali.is; Elizabeth M Gillanders - lgilland@mail.nih.gov; Bjarni A Agnarsson - bjarniaa@landspitali.is; Gudrun Johannesdottir - gudrunj@landspitali.is; Oskar Th Johannsson - oskarjoh@landspitali.is; Rosa B Barkardottir* - rosa@landspitali.is

* Corresponding author

Published: 17 July 2008

Journal of Negative Results in BioMedicine 2008, 7:5 doi:10.1 I86/1477-575I-7-5

This article is available from: http://www.jnrbm.com/content/7/1/5

(C) 2008 Gunnarsson et al; licensee BioMed Central Ltd.

This is an Open Access article distributed under the terms of the Creative Commons Attribution License (http://creativecommons.org/licenses/by/2.0), which permits unrestricted use, distribution, and reproduction in any medium, provided the original work is properly cited.
Received: 17 March 2008

Accepted: 17 July 2008

\begin{abstract}
Several mutations in the PALB2 gene (partner and localizer of BRCA2) have been associated with an increased risk of breast cancer, including a founder mutation, 1592delT, reported in Finnish breast cancer families. Although most often the risk is moderate, it doesn't exclude families with high-risk mutations to exist and such observations have been reported. To see if high-risk PALB2-mutations may be present in the geographically confined population of Iceland, linkage analysis was done on III individuals, thereof $6 \mathrm{I}$ breast cancer cases, from 9 high-risk non-BRCAI/BRCA2 breast cancer families, targeting the PALB2 region. Also, screening for the 1592delT founder mutation in the 9 high-risk families and in 638 unselected breast cancer cases was performed. The results indicate no linkage in any of the high-risk families and screening for the 1592delT mutation was negative in all samples. PALB2 appears not to be a significant factor in high-risk breast cancer families in Iceland and the 1592delT mutation is not seen to be associated with breast cancer in Iceland.
\end{abstract}

\section{Background}

Breast cancer is among the most frequent human cancers and the most common carcinoma in women in the Western world, where one out of every ten women is affected. A dominant pattern of inheritance is evident in approximately $5-10 \%$ of all breast cancers. To date, two main breast cancer susceptibility genes have been identified; BRCA1 and BRCA2 accounting for nearly half of highincidence breast cancer families and an increased relative risk of breast cancer by 10 - to 20-fold [1,2]. Other known breast cancer susceptibility genes such as CHEK2 and ATM have a more moderate penetrance with an increased lifetime risk of about 2- to 3-fold [2].

The PALB2 gene is a BRCA2 binding factor that ensures $B R C A 2$ function as a tumor suppressor and has been shown to cause Fanconi anemia subtype FA-N when biallelic germ-line mutations occur in the gene [3-5]. Recent studies have reported several mutations in PALB2 to be associated with an increased risk of breast cancer [6-9]. One is the founder mutation 1592delT which has been found to be present at a significantly elevated frequency in 
breast cancer families in Finland, resulting in a 4-fold increased risk to mutation carriers [6]. Although predisposing PALB2 mutations generally appear to cause moderate risk of breast cancer [8], mutations have also been found in strong hereditary breast cancer families $[7,9]$ and might thus be worthwhile searching for by linkage analysis in e.g. geographically confined populations.

Only two BRCA1 and BRCA2 mutations have been found in the Icelandic population, BRCA2 999del5 and BRCA1 G5193A, both being founder mutations explaining a large proportion of familial breast cancer in Iceland [10]. The BRCA2 999del5 mutation is much more frequent, accounting for around $40 \%$ of the hereditary cases and found in about $8 \%$ of unselected breast cancer cases and $0,4 \%$ of population based control [11]. A BRCA2 999del5 mutation is also the most frequently occurring BRCA1/2 mutation in Finland [12], and haplotype analysis of Finnish and Icelandic BRCA2 999del5 families did not exclude the possibility of a common ancient origin of the mutation [13]. The BRCA1 G5193A mutation however is very rare, found in less than $2,5 \%$ of hereditary breast cancer families and in $0,2 \%$ of unselected breast cancer cases [14]. The extreme frequency figures of these two founder mutations reflect low genetic diversity in the Icelandic population. The Icelandic population is a very young one, the country being settled by a few thousand founders about 1100 years ago. Low genetic diversity is probably explained by the relatively homogeneous group of settlers, and genetic drift resulting from repeated population bottlenecks due to diseases and famines $[15,16]$.

The aim of this study is to find out if the PALB2 gene is likely to play a significant role in breast cancer susceptibility in Iceland, by linkage analysis of high-risk nonBRCA1/2 breast cancer families with markers closely surrounding the PALB2 gene to test the possibility of a highly penetrant mutation, and by screening for the Finnish 1592 delT founder mutation in the family members and a large group of unselected breast cancer patients.

\section{Results and Discussion}

No evidence of linkage in the PALB2 region was found in any of the high risk breast cancer families [see Additional file 1]. The two markers flanking the PALB2 gene, D16S420 ( 0.58 Mb centromeric to PALB2) and D16S412 ( 0.45 Mb telomeric to PALB2), showed highly negative Lod scores of total $-4.18(\theta=0,00001)$ and -2.69 $(\theta=0,00001)$.

Several PALB2 mutations have been identified and one of them has been found as a recurrent mutation, 1592delT in Finland [6]. In light of the possible common ancient origin of the BRCA2 999del5 mutation in the Finnish and the Icelandic population we decided to screen for the
Finnish PALB2 founder mutation, 1592delT, in Icelandic breast cancer cases. The mutation was not detected in 638 unselected breast cancer cases nor in any of the 111 family members of the nine high risk breast cancer families.

The results of this study suggest that PALB2 is not a significant contributor to breast cancer in high-risk breast cancer families in Iceland. Furthermore, the results show that the 1592delT mutation appears not to be associated with breast cancer in the Icelandic population, and if occurring it would be very rare. However the results can not exclude the possibility that other PALB2 mutations causing low or moderate breast cancer risk exist in the Icelandic population. To determine that, it would be necessary to perform a PALB2 mutation screening or SNP analysis in a large cohort of breast cancer cases.

\section{Methods \\ Study population}

The sample set consisted of: 111 individuals from nine high-risk non-BRCA1/BRCA2 breast cancer families (Table 1), 38 controls to evaluate allele frequencies in the linkage analysis, and 638 unselected breast cancer cases diagnosed in the period 1987-2003. All patients contributing to the research have given their informed consent. The research has been approved by the Icelandic Data Projection Authority and the National Bioethics Committee.

\section{Laboratory Analysis}

Blood samples were lyzed and DNA extracted from nuclei according to Miller et al [17]. DNA from paraffin-embedded tissue was extracted as described by Jönsson et al [18] and from fresh-frozen tissue using the Wizard Genomic DNA Purification Kit (Promega).

Table I: Summary of the main clinical characteristics of the 9 high risk breast cancer families

\begin{tabular}{cccc}
\hline Family & $\begin{array}{c}\text { Number of } \\
\text { affected } \\
\text { individuals }\end{array}$ & $\begin{array}{c}\text { Number of typed } \\
\text { individuals } \\
\text { (affected) }\end{array}$ & $\begin{array}{c}\text { Mean age at first } \\
\text { diagnosis } \\
\text { years (range) }\end{array}$ \\
\hline 1 & 5 & $6(4)$ & $61.8(44-76)$ \\
2 & 5 & $11(5)$ & $49.4(44-64)$ \\
$3^{*}$ & 10 & $14(10)$ & $57.4(50-88)$ \\
$4^{*}$ & 9 & $17(8)$ & $54.2(38-75)$ \\
$5^{*}$ & 11 & $20(9)$ & $49.7(29-70)$ \\
6 & 6 & $11(5)$ & $57.5(35-79)$ \\
7 & 8 & $8(6)$ & $61.1(42-79)$ \\
8 & 5 & $11(5)$ & $49.6(30-66)$ \\
9 & 9 & $13(9)$ & $51.8(30-77)$ \\
\hline Total & 68 & $111(61)$ & $54.6(29-88)$ \\
\hline
\end{tabular}

*Co-occurrence of ovarian cancer in the family (one family member diagnosed). 
To evaluate linkage in the families the following microsatellite markers were used: D16S3036, D16S412, D16S420 and D16S3068 (primer sequences are available in the UCSC Genome Browser, genome assembly March 2006) [19]. Primers to screen for the 1592delT mutation were as in Erkko et al [6]. All the primers were purchased from MWG Biotech and each forward primer was 5' labeled with either FAM or HEX fluorophore reporter. The PCR conditions for all primer pairs were: 3 minutes incubation at $94^{\circ} \mathrm{C}$, followed by 35 cycles of $94^{\circ} \mathrm{C}$ for 30 seconds, $55^{\circ} \mathrm{C}$ for 45 seconds, $72^{\circ} \mathrm{C}$ for 45 seconds and a final extension at $72^{\circ} \mathrm{C}$ for 10 minutes, except for the $1592 \mathrm{delT}$ primers for which the annealing temperature was $64^{\circ} \mathrm{C}$ instead of $55^{\circ} \mathrm{C}$. The PCR products were analysed using an automated ABI PRISM $3130 \times 1$ Genetic Analyzer, alleles were called automatically using the GeneMapper software 4.0 and checked manually.

\section{Statistical analysis}

The Genetic Analysis System software (GAS) was used to check the genotyping data for Mendelian inconsistencies within the families. Genotypes which were inconsistent with Mendelian inheritance were reviewed. Any ambiguous genotypes were dropped. Allele frequencies for the microsatellite markers were calculated using founder individuals from the families as well as the control individuals using the Gconvert program [20]. Evidence for linkage was evaluated using parametric linkage analysis methods. Two-point LOD scores were calculated using the FASTLINK program, assuming a rare (frequency $=0.0033$ ) dominantly inherited disease allele. Age-dependant liability classes were defined using the modified CASH model $[21,22]$.

\section{Abbreviations}

PALB2: Partner and localizer of BRCA; BRCA1: Breast cancer susceptibility gene $1 ; B R C A 2$ : Breast cancer susceptibility gene 2; CHEK2: CHK2 checkpoint homolog (S. pombe); ATM: Ataxia telangiectasia mutated.

\section{Competing interests}

The authors declare that they have no competing interests.

\section{Authors' contributions}

HG conducted the genotyping, wrote the manuscript and participated in the statistical analysis and design of the study. AA did the pedigree analysis, participated in the design of the study and drafting of the manuscript. EMG performed the statistical analysis, participated in the pedigree analysis and in the design of the study. BAA provided biological samples and pathological information. GJ participated in handling of the DNA samples. OThJ participated in the recruiting of the cases. RBB initiated the study and coordinated it, and participated in the design and drafting of the manuscript. All authors read and approved the manuscript.

\section{Additional material}

\section{Additional file 1}

Two-point Lod scores for microsatellite markers surrounding the PALB2 gene $^{*}$ at recombination fractions $(\theta) 0.00001,0.01$ and 0.05 (gender averaged).

Click here for file

[http://www.biomedcentral.com/content/supplementary/14775751-7-5-S1.xls]

\section{Acknowledgements}

We thank the patients and their family members whose contribution made this work possible. We also thank the staff at the Department of Pathology for providing pathological information and tissue samples, the Icelandic Cancer Registry (specially G. Olafsdottir) and the the Genetical Committee of the University of Iceland (specially A.G. Hafsteinsdottir) for information on family members and the nurses at Landspitali-University Hospital (specially Asdis Emilsdottir) and the Service Center at Noatun (specially Steinunn G. Sveinsdottir) for help with blood sampling. The study was supported by The Research Council of Iceland, the Nordic Cancer Union, the Research Fund of Landspitali-University Hospital, and the Memorial Fund of Bergthora Magnusdottir and Jakob Bjarnason.

\section{References}

I. Fackenthal JD, Olopade OI: Breast cancer risk associated with BRCAI and BRCA2 in diverse populations. In Nat Rev Cancer Volume 7. Issue 12 Nature Publishing Group; 2007:937-948.

2. Stratton MR, Rahman N: The emerging landscape of breast cancer susceptibility. Nat Genet 2008, 40(I): 17-22.

3. Reid S, Schindler D, Hanenberg H, Barker K, Hanks S, Kalb R, Neveling K, Kelly P, Seal S, Freund M, Wurm M, Batish SD, Lach FP, Yetgin S, Neitzel H, Ariffin H, Tischkowitz M, Mathew CG, Auerbach $A D$, Rahman N: Biallelic mutations in PALB2 cause Fanconi anemia subtype FA-N and predispose to childhood cancer. Nat Genet 2007, 39(2):162-164.

4. Xia B, Dorsman JC, Ameziane N, de Vries Y, Rooimans MA, Sheng Q, Pals G, Errami A, Gluckman E, Llera J, Wang W, Livingston DM, Joenje $\mathrm{H}$, de Winter JP: Fanconi anemia is associated with a defect in the BRCA2 partner PALB2. Nat Genet 2007, 39(2): 159-161.

5. Xia B, Sheng Q, Nakanishi K, Ohashi A, Wu J, Christ N, Liu X, Jasin $M$, Couch FJ, Livingston DM: Control of BRCA2 cellular and clinical functions by a nuclear partner, PALB2. Mol Cell 2006, 22(6):719-729.

6. Erkko H, Xia B, Nikkila J, Schleutker J, Syrjakoski K, Mannermaa A, Kallioniemi A, Pylkas K, Karppinen SM, Rapakko K, Miron A, Sheng Q, Li G, Mattila H, Bell DW, Haber DA, Grip M, Reiman M, Jukkola-Vuorinen A, Mustonen A, Kere J, Aaltonen LA, Kosma VM, Kataja V, Soini Y, Drapkin RI, Livingston DM, Wingvist R: A recurrent mutation in PALB2 in Finnish cancer families. Nature 2007, 446(7|33):3 $16-3 \mid 9$.

7. Foulkes WD, Ghadirian P, Akbari MR, Hamel N, Giroux S, Sabbaghian N, Darnel A, Royer R, Poll A, Fafard E, Robidoux A, Martin G, Bismar TA, Tischkowitz M, Rousseau F, Narod SA: Identification of a novel truncating PALB2 mutation and analysis of its contribution to early-onset breast cancer in French-Canadian women. Breast Cancer Res 2007, 9:R83.

8. Rahman N, Seal S, Thompson D, Kelly P, Renwick A, Elliott A, Reid S, Spanova K, Barfoot R, Chagtai T, Jayatilake H, McGuffog L, Hanks S, Evans DG, Eccles D, Easton DF, Stratton MR: PALB2, which encodes a BRCA2-interacting protein, is a breast cancer susceptibility gene. Nat Genet 2007, 39(2): 165-167.

9. Tischkowitz M, Xia B, Sabbaghian N, Reis-Filho JS, Hamel N, Li G, van Beers EH, Li L, Khalil T, Quenneville LA, Omeroglu A, Poll A, Lepage 
P, Wong N, Nederlof PM, Ashworth A, Tonin PN, Narod SA, Livingston DM, Foulkes WD: Analysis of PALB2/FANCN-associated breast cancer families. Proc Natl Acad Sci U S A 2007, 104(16):6788-6793.

10. Arason A, Jonasdottir A, Barkardottir RB, Bergthorsson JT, Teare $M D$, Easton DF, Egilsson V: A population study of mutations and LOH at breast cancer gene loci in tumours from sister pairs: two recurrent mutations seem to account for all BRCAI/ BRCA2 linked breast cancer in Iceland. J Med Genet 1998, 35(6):446-449.

II. Johannesdottir G, Gudmundsson J, Bergthorsson JT, Arason A, Agnarsson BA, Eiriksdottir G, Johannsson OT, Borg A, Ingvarsson S, Easton DF, Egilsson V, Barkardottir RB: High prevalence of the 999del5 mutation in icelandic breast and ovarian cancer patients. Cancer Res 1996, 56( I6):3663-3665.

12. Sarantaus L, Huusko P, Eerola H, Launonen V, Vehmanen P, Rapakko K, Gillanders E, Syrjakoski K, Kainu T, Vahteristo P, Krahe R, Paakkonen K, Hartikainen J, Blomqvist C, Lopponen T, Holli K, Ryynanen M, Butzow R, Borg A, Wasteson Arver B, Holmberg E, Mannermaa A, Kere J, Kallioniemi OP, Winqvist R, Nevanlinna $\mathrm{H}$ : Multiple founder effects and geographical clustering of BRCAI and BRCA2 families in Finland. Eur J Hum Genet 2000, 8(10):757-763.

13. Barkardottir RB, Sarantaus L, Arason A, Vehmanen P, Bendahl PO, Kainu T, Syrjakoski K, Krahe R, Huusko P, Pyrhonen S, Holli K, Kallioniemi OP, Egilsson V, Kere J, Nevanlinna H: Haplotype analysis in Icelandic and Finnish BRCA2 999del5 breast cancer families. EurJ Hum Genet 200I, 9(10):773-779.

14. Bergthorsson JT, Jonasdottir A, Johannesdottir G, Arason A, Egilsson V, Gayther S, Borg A, Hakanson S, Ingvarsson S, Barkardottir RB: Identification of a novel splice-site mutation of the BRCA I gene in two breast cancer families: screening reveals low frequency in Icelandic breast cancer patients. Hum Mutat 1998 , Suppl I:SI95-7.

15. Helgason A, Hickey E, Goodacre S, Bosnes V, Stefánsson K, Ward R Sykes B: mtDNA and the Islands of the North Atlantic: Estimating the Proportions of Norse and Gaelic Ancestry. Am J Hum Genet 200I, 68(3):723-737.

16. Helgason A, Sigurardóttir S, Nicholson J, Sykes B, Hill EW, Bradley DG, Bosnes V, Gulcher IR, Ward R, Stefánsson K: Estimating Scandinavian and Gaelic Ancestry in the Male Settlers of Iceland. The American Journal of Human Genetics 2000, 67(3):697-7I7.

17. Miller SA, Dykes DD, Polesky HF: A simple salting out procedure for extracting DNA from human nucleated cells. Nucleic Acids Res 1988, 16(3): 1215.

18. Jönsson G, Naylor TL, Vallon-Christersson J, Staaf J, Huang J, Ward MR, Greshock JD, Luts L, Olsson H, Rahman N, Stratton M, Ringner $M$, Borg A, Weber BL: Distinct genomic profiles in hereditary breast tumors identified by array-based comparative genomic hybridization. Cancer Res 2005, 65(17):76/2-762I.

19. University of California Santa Cruz (UCSC) Genome Browser Website [http://genome.ucsc.edu/]

20. David Duffy's QIMR Homepage [http://www.qimr.edu.au/dav idD/]

21. Claus EB, Risch N, Thompson WD: Genetic analysis of breast cancer in the cancer and steroid hormone study. Am J Hum Genet 199I, 48:232-242.

22. Easton DF, Bishop DT, Ford D, Crockford GP: Genetic linkage analysis in familial breast and ovarian cancer: results from $2 / 4$ families. The Breast Cancer Linkage Consortium. Am J Hum Genet 1993, 52(4):678-70I.
Publish with BioMed Central and every scientist can read your work free of charge

"BioMed Central will be the most significant development for disseminating the results of biomedical research in our lifetime. "

Sir Paul Nurse, Cancer Research UK

Your research papers will be:

- available free of charge to the entire biomedical community

- peer reviewed and published immediately upon acceptance

- cited in PubMed and archived on PubMed Central

- yours - you keep the copyright
BioMedcentral 